\title{
Analisis Pengaruh Latihan Fisik Terhadap Kebugaran Jasmani Pemain Futsal Putri IAIN Kudus
}

\section{Analysis of the Influence of Physical Exercise on The Physical Fitness of Women's Futsal Players IAIN Kudus}

\author{
Jannatun Ni'mah $^{1}$, Atika Okta Melisa ${ }^{2}$ \\ ${ }^{1,2}$ Program Studi Tadris Biologi, Fakultas Tarbiyah, IAIN KUDUS \\ Email corespondensi : jannahnikmah23@gmail.com
}

\begin{tabular}{|c|c|}
\hline $\begin{array}{c}\text { Track Record } \\
\text { Article } \\
\text { Received :16 June } 2021 \\
\text { Publication: } 10 \text { December } 2021\end{array}$ & 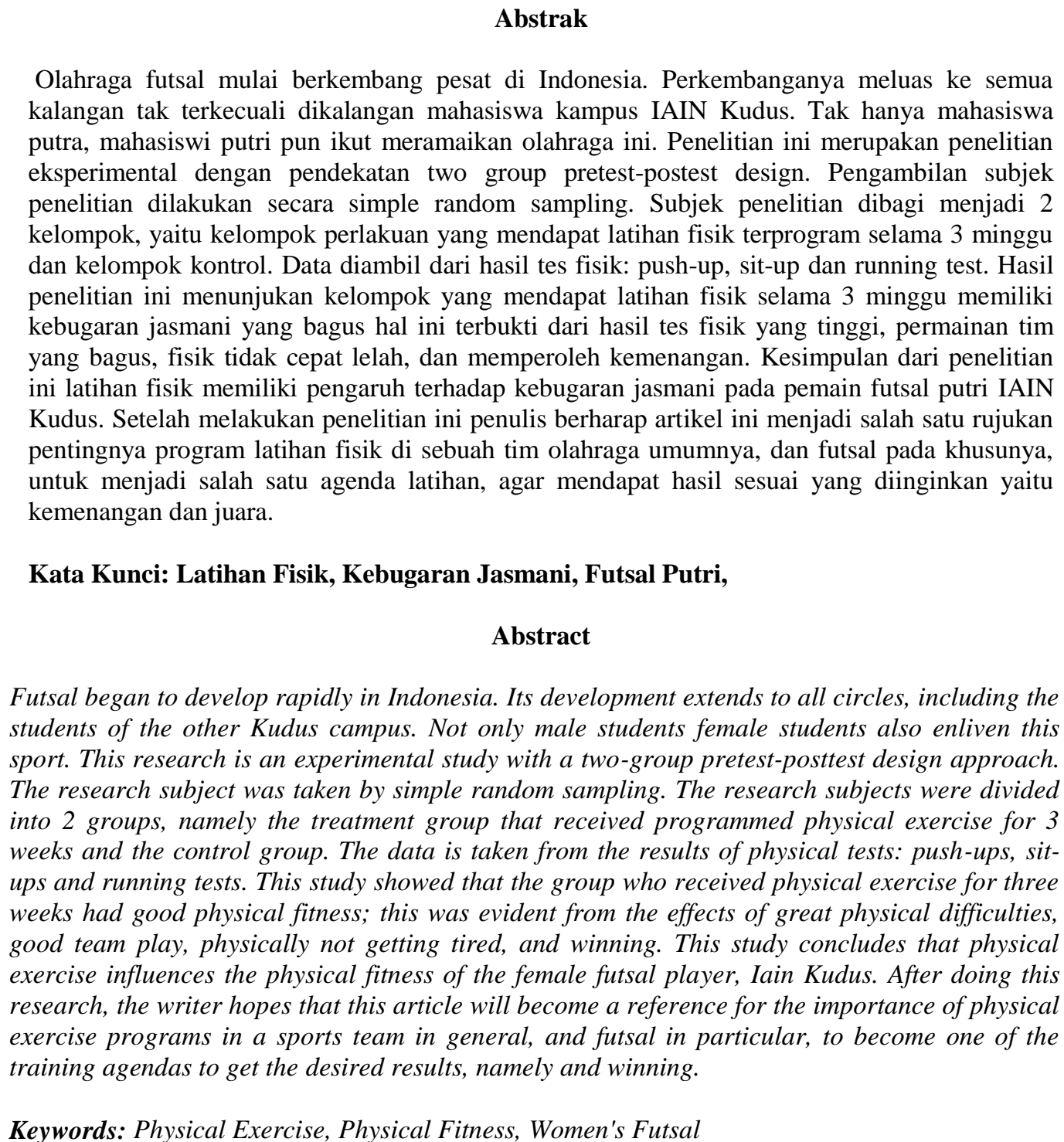 \\
\hline
\end{tabular}




\section{Introduction}

Kebugaran jasmani suatu negara dapat dijadikan sebagai barometer kesehatan negara secara keseluruhan. Dalam bidang pendidikan, kebugaran jasmani siswa merupakan faktor penting yang dapat membantu mereka mencapai keberhasilan akademik yang optimal. Kesegaran jasmani dapat dicapai semaksimal mungkin di sekolah melalui kurikulum PJOK dan kegiatan ekstrakurikuler yang mengedepankan gerak jasmani total. Kebugaran jasmani siswa dapat ditingkatkan dengan berbagai kegiatan jasmani, salah satunya kegiatan SKJ (Arifin, 2018).

Bukti yang terakumulasi dalam beberapa tahun terakhir menunjukkan bahwa mengadopsi gaya hidup sehat, yang meliputi diet sehat, latihan fisik, manajemen stres, dan interaksi sosial, dapat secara substansial meminimalkan efek merusak dari penuaan(Cvecka, 2015). Latihan fisik telah diindikasikan sebagai intervensi penting dalam perawatan yang bertujuan meminimalkan efek merusak dari penuaan, terutama sarcopenia (Ciolac, 2016). Menurut pedoman yang diterbitkan oleh Organisasi Kesehatan Dunia tentang pentingnya aktivitas fisik pada orang tua, olahraga adalah metode yang hemat biaya untuk mencegah penurunan kapasitas fungsional pada orang tua dan dapat membantu mencegah dan mengelola penyakit kronis tertentu dan kondisi (Zampieri, 2015; Bann, 2016).

Kebugaran jasmani merupakan kebutuhan yang esensial untuk aktivitas sehari-hari seseorang. Kebugaran seseorang akan memiliki dampak yang signifikan pada kinerja mereka dan juga akan membantu mereka mencapai hasil kerja atau belajar yang lebih baik (Kurniadi, 2019). Jika seseorang memiliki fisik yang bugar dan sehat, ia dapat melakukan aktivitas sehari-hari secara optimal dan maksimal, dan kebugaran fisiknya akan berdampak pada produktivitasnya di tempat kerja dan di sekolah (Widiastuti, 2015).

Olahraga futsal merupakan salah satu jenis permainan bola besar, Olahraga ini dimainkan oleh 5 pemain inti dan beberapa pemain cadangan, dengan 1 orang pemain menjadi penjaga gawang. Permainan futsal dimainkan selama $2 \times 20$ menit. Permainan ini boleh menggunakan seluruh anggota tubuh kecuali tangan. Hanya pemain yang berposisi sebagai kiper yang boleh menyentuh bola menggunakan tangan, jika selain kiper menyentuh bola menggunakan tangan dapat berakibat pelanggaran. Permainan futsal dipimpin oleh seorang wasit utama dan 2 hakim garis. Tujuan permainan futsal yaitu mencetak gol sebanyak-banyaknya ke gawang lawan, dan mencegah gawang sendiri dari kebobolan.

Prestasi dalam futsal dihitung dari jumlah kejuaraan yang diterima dan jumlah kemenangan disetiap pertandingan yang dijalani. Untuk meraih kemenangan sendiri tentu 
tidak mudah melihat pesaing tim futsal putri IAIN kudus adalah tim-tim ang solid dan memiliki jam terbang yang cukup tinggi. Dibeberapa pertandingan uji coba melawan kampus lain, tim futsal Iain kudus sering mengalami kekalahan. Menurut pelatih, salah satu faktor yang menyebabkan kekalahan tim futsal putri IAIN kudus adalah faktor lemahnya kekuatan fisik pemain, sehingga kurang maksimal dalam menjalankan instruksi dari pelatih.

Aktivitas fisik yang terencana, terkontrol, dan berulang untuk mengembangkan atau mempertahankan kebugaran tubuh disebut sebagai latihan fisik (Gahete, 2017). Aktivitas fisik dianjurkan untuk pencegahan gangguan infeksi, termasuk patologi virus, pada usia lanjut (Silveira, 2020). Mengingat situasi yang ada, banyak lansia yang hanya dapat melakukan aktivitas fisik di rumah (Nuraeni, 2019).

Latihan fisik merupakan salah satu bentuk latihan training selain latihan teknik, latihan taktik, dan latihan mental. Latihan fisik digunakan untuk mengembangkan kondisi seorang atlet. Untuk mencapai hasil optimal. Latihan fisik harus dilakukan dengan tahap sebagai berikut: 1) Pemanasan (warm up) 2) Latihan inti 3) Pendinginan (cool down). Dengan melakukan latihan fisik selama rutin 3 minggu diharapkan kondisi pemain futsal putri IAIN Kudus menjadi stabil, terjaga, dan mendapat hasil pertandingan sesuai yang diinginkan.

Suatu latihan fisik dapat dikategorikan sebagai latihan fisik yang terprogram jika meliputi faktor-faktor berikut: 1) Intensitas latihan 2) Tipe latihan 3) Lama latihan 4) Frekuensi latihan 5) Peningkatan latihan. . Indiator kebugaran jasmani yaitu 1) kekuatan 2) daya tahan 3) daya ledak 4) kecepatan 5) kelentukan 6) keseimbangan 7) koordinasi 8) kelincahan 9) ketetapan dan 10) reaksi. Untuk itu penulis bekerja sama dengan pelatih dan para pemain untuk menyukseskan program latihan fisik selama 3 minggu, latihan fisik yang dipilih yaitu push up, sit up, dan running test, latihan ini bertujuan untuk menjaga kebugaran jasmani pemain futsal putri IAIN Kudus.

Hasil penelitian Dwicahya (2017) menunjukkan latihan circuit bodyweight dapat memberikan pengaruh yang signifikan terhadap kebugaran jasamani, indeks massa tubuh, persentase lemak tubuh dan fleksibilitas. Pemilihan program latihan yang tepat dengan dosis latihan yang sesuai akan memberikan dampak yang efektif terhadap hasil yang ingin dicapai (Soni, 2017). Hasil penelitian Soraya (2019) dan Yeyen Sari (2018) menunjukkan bahwa pembina, pelatih dan guru penjas agar dapat terus memperhatikan dan memberi latihanlatihan dengan variasi terbaru yang berguna untuk meningkatkan kesehatan dan kebugaran jasmani sebagai salah satu penunjang dalam proses pembelajaran. 
Untuk menunjang performanya, setiap pemain atau atlet harus memiliki aspek kebugaran jasmani dan komponen motorik yang baik (Gumantan, 2018). Jika proses motorik adalah gerakan yang melibatkan otot secara langsung, dan proses kebutuhan yang memungkinkan seseorang untuk menggerakkan anggota tubuhnya (tangan, kaki, dan tungkai) (Fahrizqi, 2018; Yuliandra, 2018).

\section{Method}

Menurut Sugiyono (2017) populasi adalah objek atau subyek yang berada pada suatu wilayah dan memenuhi syarat-syarat tertentu berkaitan dengan masalah atau objek penelitian. Adapun yang dijadikan populasi pada penelitian ini adalah semua mahasiswa yang mengikuti UKM futsal putri di IAIN Kudus. Menurut Sugiyono (2017) mengatakan bahwa sampel adalah bagian dari populasi (sebagian atau wakil populasi yang diteliti). Jadi yang dimaksud dengan sampel dalam penelitian ini adalah seluruh siswa yang menjadi subyek dari objek dalam penelitian. Sampel yang dipilih dalam penelitian ini adalah refresentatif yang dapat mewakili pemain futsal putri IAIN Kudus secara keseluruhan. Populasi penelitian ini cukup homogen karena mempunyai beberapa kesamaan karakteristik yaitu umur yang sebaya, tingkat kemampuan bermain futsal relatif sama. Sampel yang diambil sebanyak 10 mahasiswa.

Variabel merupakan sesuatu yang menjadi objek pengamatan penelitian, sering juga disebut sebagai faktor yang berperan dalam penelitian atau gejala yang akan diteliti. Tes Latihan Fisik yang digunakan sebagai indikator kebugaran jasmani pemain futsal putri IAIN Kudus yaitu:

\section{Lari (Running test)}

Tujuan Running test adalah untuk mengukur kecepatan otot tungkai menempuh jarak lari dalam waktu yang singkat. Alat dan perlengkapan yang dipakai yaitu yaitu stopwatch, lintasan lari, dan formulir data. Pada tes ini pemain futsal putri diminta mengelilingi lapangan futsal sebanyak 5 putaran.

\section{B. Sit Up test}

Tujuan Sit Up test adalah untuk membakar kalori, menjaga kesehatan otot, meningkatkan daya tahan kardiovasular. Alat dan perlengkapan yang dipakai yaitu stopwatch dan formulir data. Pada tes ini pemain futsal diminta melakukan sit up sebanyak 30 kali dalam waktu 1 menit. 
c. Push Up test

Tujuan Push Up test adalah meningkatkan kesehatan jantung, meningkatkan pertumbuhan otot, dan mencegah osteoporosis. Alat dan perlengkapan yang dipakai yaitu stopwatch dan formulir data. Pada tes ini pemain futsal diminta melakukan Push Up sebanyak 30 kali dalam waktu 1 menit.

Penelitian ini akan menyelidiki variabel-variabel yang terlibat sesuai dengan tujuan penelitian. Variabel-variabel yang terlibat dalam penelitian ini yaitu latihan fisik dan kebugaran jasmani. Untuk menghindari terjadinya penafsiran yang meluas tentang tentang variabel-variabel yang terlibat dalam penelitian ini, maka variabel-variabel tersebut perlu didefinisikan sebagai berikut: 1. Latihan Fisik

Latihan fisik adalah suatu aktivitas yang terencana dan terstruktur yang melibatkan gerakan tubuh untuk meningatkan atau memelihara kebugaran tubuh

\section{Kebugaran Jasmani}

Kebugaran jasmani adalah kemampuan untuk melakukan kegiatan sehari-hari tanpa merasakan kelelahan yang berlebihan, serta masih memiliki cadangan tenaga untuk mengisi waktu luang dan untuk melakukan kegiatan-kegiatan yang lainya.

\section{Result and Discusion}

Kebugaran jasmani mengacu pada kondisi fisik seseorang yang berperan penting dalam aktivitas sehari-hari. Setiap orang membutuhkan tingkat kebugaran fisik tertentu. Hal ini disesuaikan dengan tuntutan tugas dan aktivitas sehari-hari. Kebugaran jasmani mengacu pada kapasitas seseorang untuk melakukan tanggung jawab pekerjaan sehari-hari tanpa menjadi lelah (Arifin, 2018). Kesegaran jasmani adalah dasar bagi kemampuan seseorang untuk melakukan aktivitas fisik atau tugas sehari-hari dengan sukses untuk jangka waktu yang lama tanpa menjadi lelah, memungkinkan mereka untuk menikmati waktu luang mereka. Kesegaran jasmani dapat dicapai dengan melakukan aktivitas fisik yang tepat, metodis, dan tidak berlebihan (Rizka, 2018). Kebugaran fisik merupakan salah satu tolak ukur dalam menentukan derajat kesehatan termasuk lansia, dengan kebugaran maka seseorang mampu melakukan aktivitas fisik dalam pekerjaan sehari-hari, karena aktivitas fisik terkait dengan kemampuan fungsional termasuk mobilitas dan kemandirian dalam aktivitas pribadi dalam kehidupan sehari-hari tanpa menimbulkan kelelahan fisik yang berlebihan dan masih dapat melakukan kegiatan lainnya (Sbardelotto, 2019). 
Tanpa pola hidup sehat yang meliputi olahraga teratur, pola makan seimbang, dan relaksasi yang tepat, tujuan memiliki tubuh yang sehat, bugar, dan ideal tidak akan terwujud. Berolahraga dengan beban tubuh merupakan program latihan yang diharapkan dapat membangkitkan minat masyarakat dan memotivasi individu untuk berolahraga, sehingga menghasilkan tingkat kebugaran yang lebih tinggi dan pencegahan berbagai penyakit. Setiap orang yang berpartisipasi dalam atletik akan mendapatkan keuntungan dari memiliki tubuh yang proporsional, tulang yang kuat, sendi yang fleksibel, dan otot yang kuat (Dwicahya, 2017).

Olahraga futsal menjadi salah satu olahraga yang popular dikalangan masyarakat. kejuaraan futsal banyak diselenggarakan mulai tingat sma, kampus bahan sampai tingkat piala dunia. Di kampus IAIN kudus terdapat kegiatan futsal yang dinaungi oleh UKM olahraga. Tak hanya futsal putra namun juga diadakan futsal putri sebagai pelengkapnya. Olahraga futsal diharapkan mampu mengharumkan nama kampus saat menjuarai suatu kompetisi.

Berdasaran penelitian yang telah penulis lakukan tim futsal putri IAIN Kudus sering mengalami kekalahan saat bertanding melawan kampus lain, faktor yang mempengaruhi kekalahan tersebut yaitu kekuatan fisik yang lemah yang menyebabkan tingkat kebugaran jasmani pemain rendah. lemahnya fisik membuat pemain futsal IAIN Kudus kurang maksimal dalam menjalanan instruksi dari pelatih. Dengan permasalahan ini penulis mencoba mencari solusi dengan melakukan program latihan fisik selama 3 minggu yang dipandu langsung oleh pelatih.

Berdasarkan penelitian yang penulis lakukan, kelompok yang terdiri dari 5 pemain yang mendapat perlakuan khusus yaitu dengan program latihan fisik seperti running test 5 putaran futsal, sit up 30 kali, push up 30 kali, diakhir latihan terlihat kelompok ini memiliki tingkat kebugaran yang bagus terbukti dengan internal game diakhir latihan yang dilasanakan selama 20 menit mengalami kemenangan selama 3 minggu berturut-turut dari tim yang menjadi kelompok kontrol.

Hasil penelitian Arifin (2018) menunjukkan bahwa terdapat pengaruh signifikan pemberian latihan senam kebugaran jasmani terhadap tingkat kebugaran jasmani siswa kelas V MIN Donomulyo Kabupaten Malang. Jalan kaki merupakan suatu kegiatan fisik yang menggunakan otot-otot terutamaotot kaki untuk berpindah dari suatu tempat atau ketempat lain. Gerak tubuh yang kita lakukan saat berjalan didominasi oleh langkah kaki, meskipun gerakan tangan dan anggota badan lainnya juga diperlukan tetapi gerak langkah kaki sebagai gerak yang utama.Jalan kaki merupakan suatu latihan olahraga yang aman mudah dan murah 
juga memiliki banyak manfat bagi tubuh (Rizka, 2018). Guru di bidang pendidikan jasmani akan memberikan kegiatan permainan olahraga di sekolah, yang akan sangat membantu pertumbuhan dan perkembangan anak secara keseluruhan.

Pada dasarnya setiap aktivitas fisik yang dilakukan secara berulang-ulang dalam jangka waktu yang lama, seperti berjalan kaki, dapat meningkatkan kebugaran jasmani seseorang. Selain meningkatkan kebugaran jasmani, oksigen yang diserap dan diedarkan saat berjalan mempercepat peredaran darah, membuat tubuh lebih cepat lelah, lebih cepat kembali ke kondisi normal, serta mengurangi stres dan depresi (Rizka, 2018). Menurut Aprilianto (2020) bahwa guru di bidang pendidikan jasmani akan memberikan kegiatan permainan olahraga di sekolah, yang akan sangat membantu pertumbuhan dan perkembangan anak secara keseluruhan.

Aktivitas fisik sangat penting untuk menjaga kesehatan dan kemandirian orangdewasa yang lebih tua mempengaruhi sistem kekebalan dan melawan virus. (Syahruddin, 2020) Olahraga teratur meningkatkan sistem kekebalan dengan mengurangi faktor inflamasi dan meningkatkan kapasitas antioksidan (Susilo, 2020). Efek positif dari olahraga, seperti Pilates, pada peningkatan efek penuaan, sudah jelas. Latihan dianggap sebagai intervensi imunoterapi. Olahraga teratur, dengan efek positifnya pada sistem kekebalan, dapat digunakan sebagai strategi untuk memperkuat sistem kekebalan orang dewasa.

Hasil penelitian Lengkong (2016) menunjukkan bahwa aktivitas fisik memiliki efek positif yaitu dapat meningkatkan kebugaran fisik dan pemeliharaan fungsional lansia. Menurut Shahrbanian (2020) bahwa olahraga latihan fisik kombinasi (latihan aerobic dan kekuatan) berpengaruh terhadap kebugaran fungsional (kekuatan, daya tahan otot, fleksibelitas, kecepatan/ kelincahan, dan kebugaran aerobic) lansia (Choi, 2020). Latihan kekuatan dan aerobik untuk populasi lansia paling efektif untuk meningkatkan fungsi neuromuskuler dan kardiorespirasi dan, akibatnya, mempertahankan kapasitas fungsional selama penuaan (Neto, 2018).

Untuk menunjang performanya, setiap pemain atau atlet harus memiliki aspek kebugaran jasmani dan komponen motorik yang baik. Jika proses motorik adalah gerakan yang melibatkan otot secara langsung, dan proses kebutuhan yang memungkinkan seseorang untuk menggerakkan anggota tubuhnya (tangan, kaki, dan tungkai).

Futsal berbeda dari olahraga lain dalam beberapa hal. Salah satu kualitas futsal adalah membutuhkan daya tahan, kekuatan, kecepatan, kelincahan, keseimbangan, dan fleksibilitas jangka panjang (Gugun, 2018). Karena permainan futsal memiliki gerakan yang cepat dan 
dinamis, maka pemain harus mampu menguasai teknik dasar dalam permainan futsal dan memiliki kondisi kebugaran jasmani yang baik, karena pemain futsal harus memiliki kebugaran jasmani yang baik dan menguasai teknik dasar dalam permainan futsal. futsal, yang berguna agar pemain tetap bermain dengan baik dalam situasi apa pun (Firmansah, 2019). Tanggung jawab pelatih untuk memastikan bahwa atlet memenuhi tujuan pelatih dan menghasilkan hasil yang memenuhi harapan, sehingga mereka dapat bersaing dengan atlet dari sekolah lain (Mubarok, 2020). Atlet harus sehat secara fisik untuk berpartisipasi dalam olahraga apa pun. Kondisi fisik atlet yang meliputi IMT, kekuatan otot, sistem saraf, keterampilan, kekuatan anaerobik, koordinasi gerak, dan daya tahan berpengaruh terhadap tingkat kebugarannya (Suryana, 2016).

\section{Conclusions}

Latihan fisik menjadi solusi yang efektif untuk meningatkan kebugaran jasmani pemain futsal putri IAIN kudus.

Berdasarkan penelitian yang sudah penulis lakukan maka penulis menyarankan kepada seluruh pengurus olahraga dan jajaran kepelatihan disemua cabang olahraga umumnya dan futsal pada khususnya untuk memasukan program latihain fisik sebagai penunjang dari menu latihan lainya. Hal ini untuk meningkatkan kebugaran jasmani para pemain. Dengan kebugaran jasmani yang bagus diharapkan prestasi dari tim olahraga IAIN kudus menjadi lebih baik lagi khususnya pada cabang olahraga futsal.

\section{References}

Aprilianto, M. V. (2020). Tingkat Kebugaran Jasmani Anggota Ukm Futsal Universitas Teknokrat Indonesia. Journal of Physical Education (JouPE), 1(1), 1-9. https://doi.org/https://doi.org/10.33365/joupe.v1i1.122

Arifin, Z. (2018). Pengaruh Latihan Senam Kebugaran Jasmani (SKJ) terhadap Tingkat Kebugaran Siswa Kelas V di Min Donomulyo Kabupaten Malang. Journal AL-Mudarris, 1(1), 22-29. https://doi.org/https://doi.org/10.32478/al-mudarris.v1i1.96

Bann. (2016). Socioeconomic differences in the benefits of structured physical activity compared with health education on the prevention of major mobility disability in older adults: the LIFE study. J Epidemiol Community Health, 70(9), 930-938. https://doi.org/doi.org/10.1136/jech-2016-207321

Choi. (2020). Effects of elastic band exercise on functional fitness and blood pressure response in the healthy elderly. International Journal of Environmental Research and Public Health, 17(9), 1-10. https://doi.org/doi.org/10.3390/ijerph1719 7144.

Ciolac. (2016). Resistance Training as a Tool for Preventing and Treating Musculoskeletal Disorders. Sports Med, 46(9), 1239-1248. https://doi.org/https://doi.org/10.1007/s40279016-0507-z. 
Cvecka. (2015). Physical Activity in Elderly. Eur J Transl Myol, 25(4), 249-252. https://doi.org/doi.org/ 10.4081/ejtm.2015.5280.

Dwicahya, N. (2017). Pengaruh Latihan Circuit Bodyweight Terhadap Kebugaran Jasmani, Indeks Massa Tubuh, Persentase Lemak Tubuh Dan Fleksibilitas. MEDIKORA, 16(1), 111-122. https://doi.org/10.21831/medikora.v16i1.23487

Fahrizqi, E. B. (2018). Hubungan Panjang Tungkai, Power Tungkai Dan Koordinasi MataKaki Dengan Kemampuan Passing Pada Pemain Unit Kegiatan Mahasiswa Olahraga Futsal Perguruan Tinggi Teknokrat. Journal of S.P.O.R.T, 2(1), 32-43.

Firmansah. (2019). Meningkatkan Keterampilan Dribbling Futsal Melalui Metode Bermain Sendiri. Jurnal Penjaskesrek, 6(1), 76-84.

Gahete, A. (2017). Fitness Assessment as anAnti-Aging Marker: A Narrative Review. Journal of Gerontologi \& Geriatric Research, 6(6), 1-10. https://doi.org/doi.org/10.4172/2167- 7182.1000455

Gumantan, A. (2018). Perbandingan Latihan Dengan Menggunakan Bola Ukuran 4 Dan 5 Terhadap Ketepatan Menendang Bola Ke Arah Gawang. Journal of S.P.O.R.T, 2(1), 1-7.

Kurniadi, D. A. E. (2019). Hubungan Kebiasaan Merokok terhadap Tingkat Kesegaran Jasmani Peserta Ekstrakurikuler Futsal Putra. Jurnal Ilmu Keolahragaan Dan Kesehatan, 1(2), 126-131.

Lengkong. (2016). Pengaruh senam bugar lansia terhadap kebugaran jantung paru di Panti Werdha Bethania Lembean. Jurnal E-Biomedik, 4(2), 1-10. https://doi.org/doi.org/10.35790/ebm.

Mubarok. (2020). Peningkatan Keterampilan Dribbling Pemain Sepakbola. Jurnal Pendidikan Olahraga, 9(1), 28-40. https://doi.org/doi.org/10.31571/jpo.v9i1.1381

Neto, A. G. de R. (2018). Effects of different neuromuscular training protocols on the functional capacity of elderly women. Rev Bras Med Esporte, 24(2), 1-10.

Nuraeni. (2019). Pengaruh Senam Lansia terhadap Tigkat Kebugaran Fisik pada Lansia Berdasar atas Uji Jalan 6 Menit. Jurnal Integrasi Kesehatan \& Sains, 1(2), 121-126. https://doi.org/https://doi.org/10.29313/jiks.v1i2. 4633

Rizka, M. (2018). Pengaruh Latihan Jalan Kaki terhadap Kebugaran Jasmani Lansia di Puskesmas Sungai Aur Kabupaten Pasaman Barat. Jurnal Stamina, 1(1), 206-218. https://doi.org/https://doi.org/10.24036/jst.v1i1.53

Sbardelotto, M. L. (2019). Improvement in Muscular Strength and Aerobic Capacities in Elderly People Occurs Independently of Physical Training Type or Exercise Model. Clinics, 74(7), 1-9. https://doi.org/https://doi.org/10.6061/clinics/201 9/e833

Shahrbanian. (2020). Physical Activity for Improving the Immune System of Older Adults During the COVID-19 Pandemic. Alternative Therapies in Health and Medicine, 26(2), $117-125$.

Silveira, D. (2020). Physical exercise as a tool to help the immune system against COVID19: an integrative review of the current literature. Clinical and Experimental Medicine, 2(3), 1-10. https://doi.org/doi.org/10.1007/s10238-020-00650-3

Soni, T. (2017). Kontribusi Kelentukan Pinggang dan Power Otot Lengan Pada Keterampilan Stutz Senam Lantai. Jurnal Kinestetik, 1(1), 1-10.

Soraya, I. (2019). Pengaruh Latihan SKJ 2018 Terhadap Peningkatan Kebugaran Jasmani Mahasiswa Putri Penjas UNIB. KINESTETIK : Jurnal Ilmiah Pendidikan Jasmani, 3(2), $249-255$.

Sugiyono. (2017). Metode Peenelitian Pendidikan Pendekatan Kuantitatif, Kualitatif, dan $R \& D$. Bandung: $\mathrm{Cv}$. Alfa Beta.

Suryana. (2016). Survei Tingkat Kebugaran Jasmani Siswa Kelas Xi Program MIA dan Program IIS di SMA Negeri 1 Trawas Kabupaten Mojokerto Thimang Ady Suryana. 
Jurnal Pendidikan Olahraga Dan Kesehatan, 4(1), 136-140.

Susilo. (2020). Coronavirus Disease 2019: Tinjauan Literatur Terkini. Jurnal Penyakit Dalam Indonesia, 7(1), 45-67. https://doi.org/10.7454/jpdi.v7i1.415.

Syahruddin. (2020). Kebugaran Jasmani Bagi Lansia Saat Pandemi Covid-19. JUARA :

Jurnal Olahraga, 5(2), 232-239.

Widiastuti. (2015). Tes dan Pengukuran Olahraga. Jakarta: Rajawali Press.

Yeyen Sari, D. (2018). Pengaruh Metode Bermain Terhadap Hasil Belajar Senam Lantai Roll

Belakang Pada Siswa Kelas VIII SMP Negeri 4 Bengkulu. Jurnal Kinestetik, 2(1), 7580. https://doi.org/https://doi.org/10.33369/jk.v2i1.9190

Yuliandra, R. (2018). Pengembangan Model Latihan Jump Shoot Bola Basket. Journal of S.P.O.R.T, 2(1), 51-55.

Zampieri. (2015). Lifelong Physical Exercise Delays Age-Associated Skeletal Muscle

Decline. J Gerontol A Biol Sci Med Sci, 70(2), 163-173. https://doi.org/doi.org/ 10.1093/gerona/glu006. 